$1-1-2016$

\title{
Biagaweit: Securing Water from the Mighty River in the Snake River Basin Adjudication
}

Jeanette Wolfley

University of New Mexico - School of Law

Follow this and additional works at: https://digitalrepository.unm.edu/law_facultyscholarship

Part of the Environmental Law Commons, Indian and Aboriginal Law Commons, and the Water Law Commons

\section{Recommended Citation}

Jeanette Wolfley, Biagaweit: Securing Water from the Mighty River in the Snake River Basin Adjudication, 52 Idaho Law Review 313 (2016).

Available at: https://digitalrepository.unm.edu/law_facultyscholarship/112

This Article is brought to you for free and open access by the UNM School of Law at UNM Digital Repository. It has been accepted for inclusion in Faculty Scholarship by an authorized administrator of UNM Digital Repository. For more information, please contact amywinter@unm.edu, Isloane@salud.unm.edu,sarahrk@unm.edu.

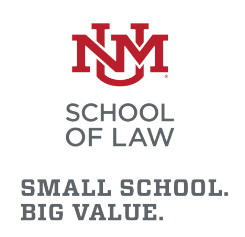

BIG VALUE. 


\title{
BIAGAWEIT: SECURING WATER FROM THE MIGHTY RIVER IN THE SNAKE RIVER BASIN ADJUDICATION
}

\author{
JEANETTE WOLFLEY
}

FULL CITATION:

Jeanette Wolfley, Biagaweit: Securing Water from the Mighty River in the Snake River Basin Adjudication, 52 IDAHO L. REV. 313 (2016).

This article Copyright (C) 2016 Idaho Law Review. Except as otherwise expressly provided, permission is hereby granted to photocopy this article for classroom use, provided that: (1) Copies are distributed at or below cost; (2) The author of the article and the Idaho Law Review are properly identified; (3) Proper notice of the copyright is affixed to each copy; and (4) Notice of the use is given to the Idaho Law Review. 


\title{
BIAGAWEIT: SECURING WATER FROM THE MIGHTY RIVER IN THE SNAKE RIVER BASIN ADJUDICATION
}

\author{
JEANETTE WOLFLEY* \\ TABLE OF CONTENTS
}

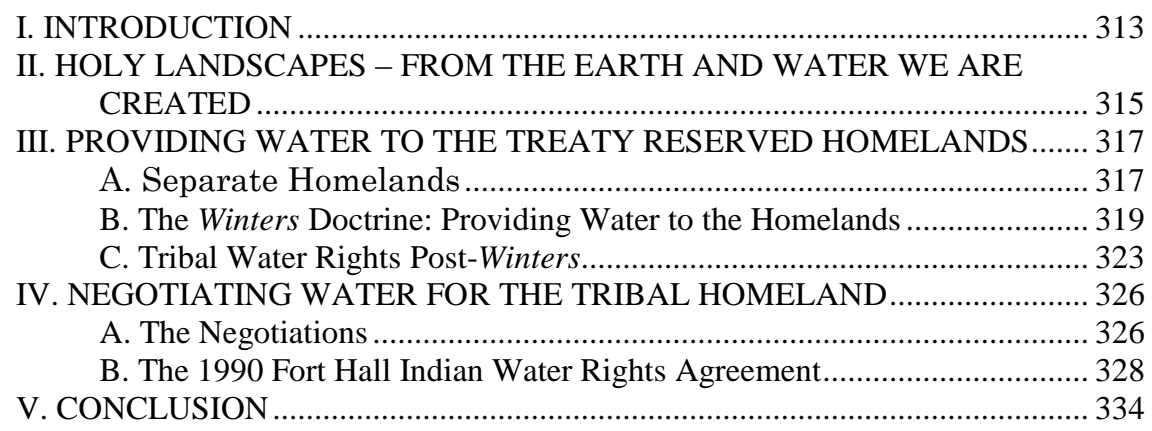

\section{INTRODUCTION}

"Biagaweit" is the Shoshone word for the Snake River. The mighty Snake River begins its journey in the Shoshone and Bannock Tribal peoples' aboriginal area (Yellowstone Park area in Wyoming), flows through the original homelands of the Bannocks ${ }^{1}$ and many Shoshone ${ }^{2}$ bands who lived on the Biagaweit in what are presently the areas of Fort Hall, Weiser, Boise, Bruneau, Raft River, Salmon River, and other southern Idaho areas, across Idaho into Oregon and ends in the Pacific Ocean. Indeed, the Snake River is named after the Shoshone as Indian tribes and early settlers referred to them as the "Snake Indians," who lived on the Biagaweit. ${ }^{3}$

* Assistant Professor, University of New Mexico School of Law. Counsel to the ShoshoneBannock Tribes on implementing the Fort Hall Indian Water Rights Agreement. Jeanette Wolfley is a member of the Shoshone-Bannock Tribes. A special "aishen" and gratitude to the Fort Hall Business Council, governing body of the Shoshone-Bannock Tribes, for their support in writing this article.

1. The Bannock call themselves "Panuquat" which translates as "from the water."

2. The word "Shoshone" derives from the word "sosoni" which is "highgrowing grass." DRUSILLA GOULD \& ChristoPHER LOETHER, AN INTRODUCTION TO THE SHOSHONI LANGUAGE DAMMEN DAIGWAPE 4 (2002).

3. Id. at 5. Gould and Loether note the origin of the word "Snake People" is based on the Indian sign language Shoshones used for themselves, which is a hand motion referring to a salmon swimming, an unknown fish on the Great Plains. Other tribes thought the sign movement represented a snake rather than a salmon, and thus referred to the Shoshones as the Snake People. 
For the Shoshone-Bannock Tribes, no single natural resource has been more culturally vital than water. ${ }^{4}$ As reflected in Tribal cosmologies, oral traditions, history, and ceremonies, the physical, social, and spiritual sustenance that water provides frames all aspects of Tribal communal life and experience. From the time of creation, water has shaped who the Shoshone and Bannock peoples are, how they approach water matters, and our overall perspective of water. Accordingly, Biagaweit and other rivers, lakes, streams, creeks, and springs, and their related environments throughout Idaho and beyond continue to be an integral part of Tribal lifestyle today.

Prior to the Snake River Basin Adjudication (SRBA) the numerous tribes in Idaho held unquantified senior water rights throughout the state. In the absence of quantification, however, non-Indians have been using Indians' senior water rights for many decades. In the state of Idaho, the water rights of three tribes, the Shoshone-Bannock Tribes, the Shoshone-Paiute Tribes and Nez Perce Tribe, residing on three Indian reservationsFort Hall, Duck Valley, and Nez Perce - have been quantified in the general stream adjudication of the SRBA. ${ }^{5}$ Each tribe reached a negotiated settlement agreement tailored to address the specific issues and challenges faced by the parties - the Tribes, United States, State of Idaho and other affected groups. The Coeur d'Alene and Kootenai Tribes' water rights remain to be adjudicated.

This symposium article describes the Shoshone and Bannock peoples' journey to quantify their water rights in the SRBA. It begins with the Shoshone-Bannock Tribal cultural perspective on water and water rights. It then discusses the concept of tribal homelands and the water required and necessary for sustaining a tribally reserved home as guaranteed in the Fort Bridger Treaty of 1868, including a discussion of the Winters doctrine which affirms the treaty's promises. It concludes with a review of the Fort Hall Indian Water Rights Agreement. ${ }^{6}$

4. In this paper I do not attempt to express a voice on behalf of all Indian tribes as it certainly would be a daunting task. Instead, my voice comes from the traditions and values of the Shoshone-Bannock peoples.

5. In re SRBA, Case No. 39576, The Partial Final Consent Decree Determining the Rights of the Shoshone-Bannock Tribes to the Use of Water in the Upper Snake River Basin (1995); In re SRBA, Case No. 39576, Order Amending Partial Final Consent Decree Determining the Rights of the Shoshone-Bannock Tribes to the Use of the Water in the Upper Snake River Basin to Correct Clerical Error, I.R.C.P. 60(a) (2005); In re SRBA, Case No. 39576, Revised Consent Decree Approving Entry of Partial Decrees Determining the Rights of the United States as Trustee for the Benefit of the Shoshone-Paiute Tribes to the Use of Water in the Snake River Basin within Idaho (2006); In re SRBA, Case No. 39576, Consent Decree Approving Entry of Partial Final Decrees Determining the Rights of the United States as Trustee for the Benefit of the Nez Perce Tribe and the Nez Perce Tribe to the Use of Water in the Snake River Basin with Idaho and Partial Final Decrees Determining Minimum Stream Flow Water Rights Held by the Idaho Water Resources Board (2007).

6. The 1990 Fort Hall Indian Water Rights Agreement, Idaho-Shoshone-Bannock-U.S., July 71990, http://www.idwr.idaho.gov/WaterManagement/WaterDistricts/PDF/BC/PDF/ 1990_Ft_Hall_Agreement.pdf [hereinafter Agreement]. “'The 1990 Fort Hall Indian Water Rights Agreement' as ratified by the Shoshone-Bannock Tribes in June, 1991, and as approved by the United States in Public Law 101-602, 104 Stat. 3061, on November 16, 1990, and as approved by the State of Idaho in 1991 Idaho Session Laws Chapter 228 at 547.” IDAHO ADMIN. CODE r. 37.02 .04 (2012) 


\section{HOLY LANDSCAPES - FROM THE EARTH AND WATER WE ARE CREATED}

Let me begin with a story. ${ }^{7}$ When our people are young, they are told wonderful stories ${ }^{8}$ about the Creator, about how this world was created, and how our people came to be in this world. Tribal people speak of history in terms of worlds. We are told that in the First World the following Creation occurred (abbreviated version):

There was a time when there was only water. The Creator blew down on the light foam that formed on the water and called, "Water People, where are you?" The first time he called, Beaver came up and asked, "Why am I here?" Beaver talked, sang and smoked with Creator. Beaver was asked to dive back into the water. Beaver painted himself with bright colors and dived back into the water. Creator waited for the Beaver for three days, but Beaver did not come back.

Creator blew away the foam from the water again, and called "Water People, where are you?" Otter appeared and asked, "Why am I here?" Otter sang, smoked and talked with the Creator. Otter placed bright colors over his body and dived back into the water. Creator waited three days but Otter did not return.

Creator separated the foam and again called, "Water People, where are you?" Soon, Muskrat, youngest of the water people came out of the water and asked, "Why am I here?" Muskrat sang, smoked and listened to the Creator. Creator asked Muskrat to dive deep into the water. With bright colors painted on his body, Muskrat dived back into the water. He went straight and very, very deep. Down, down he went. Creator waited. On the third day, Creator saw Muskrat floating in the foam looking dead. Creator was sad and cried because he had lost his youngest of the Water People.

Creator lifted dead Muskrat into his hands. As he held Muskrat, Muskrat began to breathe. Creator looked carefully at Muskrat, and found mud on Muskrat's nose. Creator was joyful and rejoiced as Muskrat had completed the Creator's task. Creator took the mud from the nose of Muskrat and rolled and rolled the mud, round and round between the Creator's hands the mud was molded. Creator shaped the mountains, the valleys. Creator shaped rivers and oceans. Father shaped the earth. And, finally, Creator shaped the People, the Shoshone and Bannock People.

7. Our stories matter. One reason why they matter is because Indian tribes are still here, and we intend to be here for many generations to come. Another reason is that by state, federal and others knowing our stories about the natural world they thereby gain a wider understanding of Shoshone-Bannock peoples. For a review of the importance of Indian oral traditions, see generally VINE DELORIA, JR., GOD IS RED: A NATIVE VIEW OF RELIGION (2d ed. 1994).

8. The Shoshone and Bannock peoples, as with other Indian nations, have an oral history and tradition. Because our culture exists orally through a process of storytelling, it is not proper to offer citations to books or other documents for these stories. January is considered the longest month of the year. It is then that the nights are longer and colder than any other time. This is the time when the older people tell stories to their children and grandchildren. Grandfather is the storyteller of the family among the Shoshone-Bannock people. He is the one who passes on to the younger generation the stories, teachings and instructions which have been handed down through the ages from generation to generation. 
This is the Shoshone and Bannock peoples' abbreviated version of how the world was created, of how we were created as a people, and our holy land ${ }^{9}$. The Shoshone and Bannock people understand the importance of water, the water people, plants and medicines, earth and their source, and their interconnection based on the Creation story. We know that we are from the water, and we are shaped from the earth. Consequently, protection and preservation of these resources, the holy landscapes, are thus extremely vital to the Tribes, as the Creation story is a foundation upon which Tribal society functions. Ordinarily, the Tribal Creation story and others related to water are not shared as part of any water meetings, negotiations or discussion, but are certainly very much a part of Shoshone and Bannock peoples' prayers, thinking and values relied upon in decision-making, and in preparing positions and policies of the Tribes.

When Shoshones and Bannocks say "water is life," they are speaking in terms of their Creation story, where they originated, and thus give respect and reverence to their place of origin. They also mean that water is a living being or spirit that has healing powers. And, finally, they know that all human and non-human beings must have water to survive. For those reasons, Tribal people understand and carry responsibilities to fulfill and sustain their core values surrounding water.

It is not surprising that Shoshone and Bannock people lived near the water-the streams, rivers, lakes, creeks and hot springs - as they sought to maintain their connection and relationship with their holy landscape. The place of their creation. And, Biagaweit is and continues to be a central component of Shoshone and Bannock peoples' life. The natural landscapes and its resources were incorporated and developed into their overall cultural system. The Shoshone and Bannock prayed, sang and gave offerings to the water and land. Indeed, they use the water in ceremonies of all kinds and today - the Sundance, the Sweatlodge, the Ghostdance, and Native American Church. Blessing the areas with water where the People gathered was always critical and we continue to use the water with our daily prayers.

Shoshone and Bannock peoples have a special relationship with their land and water which they see as imbued with a spirituality and sacredness not generally understood by others. Water, the giver of life, has enabled the Tribes to survive for thousands of years. The reverence for water and its blessings continue to shape and support the Tribal political, social, cultural and economic climate of the Shoshone-Bannock Tribal community. To the Tribes, water and its meaning is timeless. The land and water for them is more than just a habitat or political boundary; it is the basis of the Tribes origin, and cultural identification. The Tribal values, customs and norms are used to address contemporary legal issues such as the Snake River Basin Adjudication. Indeed, from the time of creation, water has shaped who the Shoshone and Bannock peoples are, how the Tribes approach water matters, and our overall perspective of water. Indeed, it is the Creation Story that gave guidance to the Tribes in the SRBA.

9. The phrase "holy lands" or "holy landscapes" is often used to explain one of the broadest and most fundamental connections between Native American people and the land or water. "Holy land" is a term that uses a common perception to convey to non-Indian people the cultural significance of Indian land perceptions. A holy land is often created by a being who establishes an origin or birthright relationship between a people and that portion of the earth where they were created. This relationship provides the people with certain rights to use and obligation to protect resources on that portion of the earth. The holy place includes living surfaces above and below this earth. 


\section{PROVIDING WATER TO THE TREATY RESERVED HOMELANDS}

From a legal standpoint, treaties between Indian tribes and the United States, federal statutes, federal Indian policies, and federal court decisions all recognize the inherent right of tribal people to their culture, language, land and water. This section will review the reservation of tribal lands and the provision of water to those lands for present and future generations through court decisions establishing the foundation for tribal priority to water in stream adjudications are discussed.

\section{A. Separate Homelands}

There are some 322 living Indian communities (reservations) in America. ${ }^{10}$ Each has its dreams and challenges. Nearly all share a common loss of their land to an immigrant majority population with a colonist persuasion. And the vast cessions of land by the Tribal peoples were premised on federal solemn promises that the native peoples could continue their way of life on homelands of smaller size, free from the intrusions of the majority non-Indian society. ${ }^{11}$

Since the beginning of federal-tribal relations, Indian tribes have fought in war, in Congress, in courts, and in public forums to maintain a separate existence apart from the majority society. Indeed, the promise by the United States of separatism in perpetuity was a fundamental premise underlying the treaty negotiations with the tribes of the lower forty-eight states. ${ }^{12}$ Even today, tribal separatism remains a focal point for modern Indian policy.

Tribes across the country relinquished millions of acres of land in exchange for assurances of a retained permanent homeland of smaller size in which they would remain free from federal and state interference and the intrusions of non-Indian settlers. ${ }^{13}$ These promises are memorialized in the various treaties executed by tribal leaders and federal agents, and as confirmed by the United States Senate. ${ }^{14}$ Indeed, for people with close physical and spiritual connections to the water and earth, preserving the new reservation land bases was essential to preserving tribal cultures and existence. In many respects, the promise of tribal sovereignty has survived only because of the measured separatism ${ }^{15}$ made possible by the retained tribal land base.

10. David H. Getches et al., Cases and Materials on Federal Indian Law 9 (6th ed. 2011).

11. Phillip P. Frickey et al., Cohen's Handbook on Federal Indian Law $§ 1.03[6][a]$, at 60 (Nell Jessup Newton et al. eds., 2012).

12. See Charles F. Wilkinson, American Indians, Time And The Law: Native Societies IN A MODERn CONSTITUTIONAL DEMOCRACY 18 (1987); Mary Christina Wood, Indian Land and the Promise of Native Sovereignty: The Trust Doctrine Revisited, 1994 UTAH L. REv. 1471 (1994).

13. Jeanette Wolfley, As Long As The Water Shall Flow: Bringing Water to Tribal Homelands, 62-APR FED. LAW. 50, 51 (2015).

14. Id.

15. Wilkinson describes "measured separatism" as:

Implicit ... was not only the expectation that each tribe would remain a people, but also the perception that a homeland, separate and distinct from the surrounding white culture, was a requisite element of that survival....

The essence of these laws, then, as viewed both by Indian tribes and by the United States, was to limit tribes to significantly smaller domains but also to preserve substantially intact a set of societal conditions and tribal prerogatives that existed then.

Wilkinson, supra note 12 , at 18. 
For example, the 1868 Treaty of the Shoshone and Bannock guaranteed a reservation for the "absolute and undisturbed use and occupation" of the Tribes, ${ }^{16}$ and as a "permanent home." 17 Many treaties also contained express assurances that the federal government would protect the tribes. ${ }^{18}$ While individual treaties differ from tribe to tribe all were oriented toward ensuring the perpetual availability of a sustained land-based, tradition existence for tribes. Nearly all promised a permanent homeland, and many included assurances of continued rights to fish, hunt and gather for subsistence. ${ }^{19}$ The vast majority of treaties contained federal promises to provide food, clothing, and services to the tribes. ${ }^{20}$ Several treaties also provided that the federal government, would ensure the tribes peaceful existence by restraining a sometimes hostile non-Indian population. ${ }^{21}$

This tribal separatism withstood the most devastating attack by Congress in the late 1800's under the General Allotment Act of 1887, also known as the "Dawes Act." 22 Under the allotment policy, Congress attacked the basic tribal value and cultural practice of holding land in common for all tribal members to use and occupy. The General Allotment Act approach was to remove land held in tribal ownership, divide it into parcels of 90, 180 or 360 acres, and distribute it to individual tribal members and families. ${ }^{23}$ Congress ultimately repudiated this allotment policy when it enacted the Indian Reorganization Act in $1934,{ }^{24}$ but by the end of the allotment era Indian tribes and individuals held only a third of the land that the tribes had held in $1887 .{ }^{25}$ Viewed from the late twentieth century perspective, the General Allotment Act can be seen for what it was - an attempt to carry out cultural genocide against indigenous people. ${ }^{26}$

Today, the remaining tribal land base or homeland is the sine qua non of sovereignty. Tribal territories provide an irreplaceable forum for cultural vitality based on religious practices and cultural traditions premised on the sacredness of land. Fully functioning Indian nations possess four distinct yet interwoven and interdependent attributes

16. Treaty with the Eastern Band of Shoshonis and Bannock, art. 2, July 3, 1868, 15 Stat. 673 [hereinafter Fort Bridger Treaty]. This Treaty is more commonly known as the "Fort Bridger Treaty of $1868 . "$

17. Id. at art. 4 .

18. Id. at art. 1; see also Wilkinson, supra note 12, at 15-16.

19. Fort Bridger Treaty, supra note 16, at art. 4; see also Wilkinson, supra note 12 at 1.

20. Fort Bridger Treaty, supra note 16, at art. 3, art. 7, art. 9, art. 10.

21. Under Article 1 of the Fort Bridger Treaty, the United States provided, "If bad men among the whites, or among other people subject to the authority of the United States, shall commit any wrong upon the person or property of the Indians, the United States will . . proceed at once to cause the offender to be arrested and punished according to the laws of the United States, and also reimburse the injured person for the loss sustained." Fort Bridger Treaty, supra note 16, at art. 1.

22. 24 Stat. 388 (1887); see generally Judith V. Royster, The Legacy of Allotment, 27 ARIZ. ST. L.J. 1, 7-12 (1995).

23. 25 U.S.C. $§ 461(2012)$.

24. $I d$.

25. The results of allotment included the loss of an enormous amount of Indian land. The Indian land base of 138 million acres at the enactment of the General Allotment Act was reduced to 48 million acres by enactment of the Indian Reorganization Act in 1934. DENNIS BINDER ET AL., COHEN'S HANDBOOK OF FEDERAL INDIAN LAW 138 (1982 ed.).

26. See generally Rennard Strickland, Genocide-at-Law: An Historic and Contemporary View of the Native American Experience, 34 U. KAN. L. REV. 713 (1986). 
of sovereignty: secure land base, functioning economies, self-government and cultural vitality. ${ }^{27}$ Some describe these attributes as geographic and political independence. ${ }^{28}$

In short, the tribes' land bases are the linchpin to tribal existence and autonomy as sovereign nations. Indeed, a priority implicit in Indian land tenure is maintaining a homeland in which both present and future generations of the tribes may live and flourish because tribal individuals and families reside on secure land bases which have supported and nourished their ancestors for thousands of years past, and continue to be the core and integral foundation of tribal existence. Tribal lands are home to the tribal government, tribal people, tribal culture, and tribal society.

In the end, tribes sacrificed most of their ancestral lands for assurances in treaties that they would be protected in their new homelands. These treaty promises have not been expressly repealed or amended. Today, these treaty provisions securing a separate reserve are the beginning point for modern federal Indian law and policy in the area of water law because without water for the tribal homeland there would be no habitable place for the tribal people. To the Tribes, the primary task always has been not just to survive but to build a viable homeland for their people. The original promise of separatism in the treaties has faced challenges and bumps in the road through changes in society, federal policies and judicial decisions. ${ }^{29}$ Still, the tribes seek to ensure that water is available for their homelands, for their people.

\section{B. The Winters Doctrine: Providing Water to the Homelands}

The United States Supreme Court confirmed the $19^{\text {th }}$ century treaty promises of a continuing tribal homeland in Winters v. United States. ${ }^{30}$ The Winters Doctrine is the doctrine relied upon by most tribes in seeking to secure water rights in general stream adjudications pending in state courts in virtually every western state. ${ }^{31}$ There are also other categories of Indian water rights - aboriginal, ${ }^{32}$ Pueblo, ${ }^{33}$ and rights acquired under

27. Various scholars have discussed one or more of these attributes as vital to tribal existence. See Robert N. Clinton, Isolated in Their Own Country: A Defense of Federal Protection of Indian Autonomy and Self-Government, 33 STAN. L. REv. 979, 982-84 (1981); Mary Christina Wood, Protecting the Attributes of Native Sovereignty: A New Trust Paradigm for Federal Actions Affecting Tribal Lands and Resources, 1995 UTAH L. REV. 109 (1995) (for a superb discussion of the attributes).

28. See Wilkinson, supra note 12.

29. Federal Indian policies has shifted back and forth from supporting separatism to assimilation of tribal people into the mainstream society. Beginning in 1975, the current federal policy era of Tribal SelfDetermination supports tribal self-government and self-sufficiency.

30. 207 U.S. 564 (1908).

31. Id.

32. Some Indian reservations are located in the ancestral homeland of the current tribal members. If an Indian tribe is residing on a reservation that encompasses part of its ancestral homeland, one basis for a water rights claim is aboriginal rights. The concept of aboriginal water rights recognizes that the federal government did not "give" the tribes anything when it created the reservation. The reservation was simply a limitation on what the United States was granted by the tribes. Aboriginal water rights have a priority date of immemorial. Under the doctrine of aboriginal rights, it is necessary to establish that the tribes used the water. As with the Winters doctrine, aboriginal rights are not lost through lack of use.

33. Indian reservations in New Mexico can have Pueblo water rights, which are recognized as federal rights. The residents of the Pueblos had legal water rights recognized by the Spanish and, later, the Mexican governments. Under the terms of the Treaty of Guadalupe Hidalgo, the United States agreed to honor the water rights granted to the Pueblo Indians. In New Mexico ex rel. State Engineer v. Aamodt, the 
state law, which can be used in various combinations in presenting an Indian reservation's water rights claims.

"The now landmark case of Winters v. United States, involving the Milk River along the Fort Belknap Indian Reservation in northern Montana, simply states that when the federal government established a reservation, the government implicitly reserved a quantity of water necessary to fulfill the purposes of the reservation." ${ }^{34}$ Consequently, when the United States sets aside lands as an Indian reservation, it reserves water to provide a home for the Indian tribes residing on those lands. ${ }^{35}$ The Court established that the priority of the Winters water rights dates back to the establishment of the reservation. ${ }^{36}$

Reservation purposes are implied after careful examination of the original documents establishing a reservation. Generally, all origination documents imply, if not explicitly recite, that the reservation was established to become the "permanent home" for the said Indian tribe. ${ }^{37}$ In Article 2 of the Fort Bridger Treaty, the Fort Hall Reservation was reserved as the "permanent home" for the Shoshone and Bannock Tribes. ${ }^{38}$ Other reservations were established with the broad intent that the Indians become "pastoral and civilized people" (e.g., nomads to agriculturalists). ${ }^{39}$ Thus, all Indian reservations necessarily imply that the tribe reserved water for the broad purpose of developing a permanent homeland. ${ }^{40}$ These broad purposes entitle a tribe to sufficient water for agricultural, livestock, domestic, cultural, recreational, and other future uses. ${ }^{41}$

In Winters, the United States brought suit on behalf of the Gros Ventre and Assiniboine Indians of the Fort Belknap Indian Reservation in northern Montana to halt upstream diversions by non-Indians who had been using waters from the Milk River since 1900. ${ }^{42}$ The center line of the Milk River formed the northern boundary of the Reservation and the residents of the Reservation used the water primarily for agricultural irrigation. ${ }^{43}$ Non-Indian diverters built dams and canals on the Milk River upstream from the Reservation and "deprived the United States and the Indians of the use [of the water]." 44 The non-Indian diverters claimed that they were prior appropriators of the water, and were therefore entitled to the right to divert the Milk River. ${ }^{45}$

The United States Supreme Court held that the language of the Act of May 1, 1888 ("1888 Act"), ${ }^{46}$ which established the Fort Belknap Reservation was pivotal. The Act ratified the Gros Ventre and Assiniboine cession of "a very much larger tract which the

federal court ruled Pueblos are entitled to aboriginal water rights based on how many acres each had historically irrigated at any time between 1846 and 1924. 618 F.Supp. 993 (D.N.M. 1985). The court also ruled that the Pueblos were entitled to satisfy their rights either from surface water or hydrologically connected groundwater. Id.; see also the Aamodt Litigation Settlement Act of 2010, Pub. L. No. 111-291, 124 Stat. 3064 (Pueblos of Nambe, Pojoaque, San Ildefonso, and Tesuque), settling the water claims by four Pueblos in New Mexico.

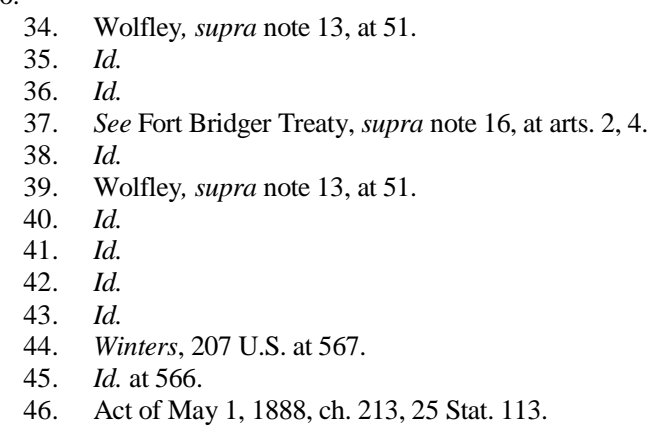


Indian had the right to occupy and use, and which was adequate for the baits and wants of the nomadic and uncivilized people. ${ }^{47}$ In exchange for their cession, the Gros Ventre and Assiniboine Tribes agreed to live on the Fort Belknap Reservation, undisturbed by non-Indians. ${ }^{48}$ The Tribes also agreed to give up their hunting and gathering lifestyle "and to become a pastoral and civilized people." 49

The Treaty did not mention water rights. However, the arid land which became the Fort Belknap Reservation could not support such a pastoral lifestyle without irrigation from the Milk River. ${ }^{50}$ Accordingly, the Court held that the Indians could not have ceded their rights to water for use on the Reservation under the 1888 Act, contrary to the arguments of the non-Indian diverters:

The Indians had command of the lands and the waters - command of all their beneficial uses, whether kept for hunting, "and grazing roving herd of stock," or turned to agriculture and the arts of civilization. Did they give up all this? Did they reduce the area of their occupation and give up the waters which made it valuable or adequate? And, even regarding the allegation of the answer as true, that there was springs and streams on the reservation flowing about 2,900 inches of water, the inquiries are pertinent. If it were possible to believe affirmative answers, we might also believe that the Indians were awed by the power of the government or deceived by its negotiations. Neither view is possible. The government is asserting the rights of the Indians. ${ }^{51}$

The Supreme Court recognized that treaty reserved water rights encompass those rights which the tribes did not relinquish in their cessions of territory to the United States. ${ }^{52}$ The non-Indian diverters did not, as a result, have prior appropriative rights to divert the Milk River upstream from the Reservation, since the Gros Ventre and Assiniboine Tribes never ceded the Milk River's waters. ${ }^{53}$ Instead, the Tribes had senior water rights at least as early as the establishment of the Fort Belknap Reservation. ${ }^{54}$

Importantly, Indian reserved water rights arise by implication drawn from the treaty, statute, or executive order, not through compliance with state water procedures. ${ }^{55}$

47. Winters, 207 U.S. at 576.

48. $\quad I d$.

49. Id.

50. Id.

51. $\quad I d$.

52. $I d$.

53. The principal that in treaties between Indian tribes and the United States, those rights which were not expressly relinquished were reserved for the benefit of the tribe arose three years before Winters in an off-reservation fishing rights case involving Yakama Indians in Washington. United States v. Winans, 198 U.S. 371, 381 (1905) (the Court reasoned the Yakama Nation reserved a fishing right by implication: "the treaty was not a grant of rights to the Indians, but a grant of right[s] from them, a reservation of those not granted." And, state law could not interfere with this right reserved under federal law); see also United States v. Rio Grande Dam \& Irrigation Co., 174 U.S. 690, 699-700 (1889) (state law appropriators could not use so much water as to destroy the United States' retained right of navigation, neither could those acquiring land pursuant to state law defeat the terms of the Yakama Treaty, also a reservation of rights by the Indians).

54. See generally Winters, 207 U.S. 564.

55. Reid Peyton Chambers \& John E. Echohawk, Implementing the Winters Doctrine of Indian Reserved Water Rights: Producing Indian Water and Economic Development Without Injuring Non-Indian Water, 27 GoNZ. L. REV. 447, 468 (1991-1992). 
Accordingly, the water rights are established as of the date of the federal reservation. ${ }^{56}$ This makes the water right "senior" to any private state water rights which may have arisen subsequent to the creation of the reservation. ${ }^{57}$ It is this point, which many state water rights users claim intrudes on the authority of states to allocate water. ${ }^{58}$

Today, the majority of Indian water rights are based on the Winters doctrine or reserved rights doctrine, which is neither an appropriative or riparian right. ${ }^{59}$ Winters rights are reserved rights established under federal law when Indian tribes reserved their homelands by treaty, statute or executive order ${ }^{60}$ Reservation of the water right is implied by the purpose establishing the reservation, which can be a narrow purpose such as to promote agricultural lifestyle, ${ }^{61}$ or a broader purpose to prove a permanent homeland for a tribe. ${ }^{62}$

Several fundamental principles characterize the Winters doctrine, and are critically important in today's prior appropriation water regimes:

1. The priority date of a water right on an Indian reservation is the date the reservation was created, unlike state appropriative rights, which take a priority date from the time the water is first put to beneficial use. ${ }^{63}$ In most instances, the establishment of an Indian reservation pre-dated statehood and uses by nonIndians, and therefore, are senior to most other rights in the West.

2. Tribal reserved water rights are a federal right paramount over state water rights.

3. Tribal reserved rights are not lost by non-use of the water rights, by a forfeiture, or an abandonment of the water right under state law.

The modern implications of the Winters doctrine are far-reaching and have become all the more significant as populations increase, municipalities grow, and the overall demands of the United States' water supply increase. The Winters doctrine and federal reserved rights doctrine ${ }^{64}$ have become deeply ingrained in western water law. However, it is not popular with states and non-Indian water users who view it sometimes as an aberration in the state prior appropriation law and upsets often settled expectations of property rights. Yet, the Winters doctrine has not gone away, it continues to govern Indian water rights today. It has been confirmed and applied by the U.S. Supreme Court eight times. ${ }^{65}$

\footnotetext{
56. Id.

57. $I d$.

58. Id.

. 59. $I d$.

60. Id.

61. In re Gen. Adjudication of All Rights to Use Water in Big Horn River Sys., 753 P.2d 76, 112
} (Wyo. 1988), aff'd, 492 U.S. 406 (1989).

62. In re Gen. Adjudication of All Rights to Use Water in the Gila River Sys. and Source, 35 P.3d 68, 76 (Ariz. 2001) (Gila V) (For a discussion of this case, see generally Barbara A. Cosens, The Measure of Indian Water Rights: The Arizona Homeland Standard, Gila River Adjudication, 42 NAT. RESOURCES J. 835 (2002)).

63. See generally 1 Waters and Water Rights $§ 12.02$ (Robert E. Beck \& Amy K. Kelley, eds., 3d ed. LexisNexis 2009).

64. See generally Fed. Power Comm'n v. Oregon, 349 U.S. 435 (1955) (relating to the Pelton Dam, the Supreme Court suggested that the Winters doctrine went beyond water rights for Indian tribes and stood for the proposition of a general "federal reserved water rights" doctrine).

65. See generally United States v. New Mexico, 438 U.S. 696 (1978); Cappaert v. United States, 426 U.S. 128 (1976); Colorado River Water Conservation Dist. v. United States, 424 U.S. 800 (1976); United 


\section{Tribal Water Rights Post-Winters}

The landmark Winters case was decided in 1908. And yet, for over 50 years the United States rarely sought to protect or secure tribal claims to water. ${ }^{66}$ Instead, during this period of time, the United States' policy was to support and encourage settlement in the West by constructing irrigation projects that flowed through or bordered Indian reservations. ${ }^{67}$ The federal government built mammoth dam and reservoir projects and water systems for non-Indian irrigators and states. ${ }^{68}$ Additionally, the federal government supported the creation of family-sized farms on arid lands under numerous federal laws including the Homestead Act ${ }^{69}$ and the Desert Land Act. ${ }^{70}$ In short, the United States was far more interested in encouraging non-Indian settlement than it was in developing and protecting Indian water resources.

The result was western states issued water rights permits to farms, cities, and industries without recognizing Indian water rights. ${ }^{71}$ Water was diverted and is used today by farmers, developers, and communities. ${ }^{72}$ Water flowed to non-Indian fields and desert lands. ${ }^{73}$ Cities boomed in the West and water is treated as a commodity. ${ }^{74}$ Still, tribal reserved water rights went unquantified..$^{75}$

Today, the scarcity of water caused by over appropriation, overuse, and inadequate laws and policies has caused alarm in many communities. The uncertainty of how much the senior tribal water right will be as confirmed in court decree following litigation or negotiated in a water rights settlement is a major concern to non-Indian irrigators or local governments. Another concern is that if unexercised senior Indian water rights are actually put to use in water short areas, non-Indian use would be drastically reduced, and disruption would occur in the economies and capital investments.

The Supreme Court in Winters did not address how much water tribes were to receive under the doctrine. It was not until 1963, in Arizona v. California, ${ }^{76}$ that the Supreme Court provided some guidance on the quantification issue. In the case, a Special Master recommended that the arid Indian reservations in question had an agricultural purpose, and that the Indian reserved water rights should be measured on the basis of a

States v. Dist. Court for Eagle Cty., 401 U.S. 520 (1971); Arizona v. California, 373 U.S. 546 (1963); Federal Power Comm'n v. Oregon, 349 U.S. 435 (1955); United States v. Powers, 305 U.S. 527 (1939); Winters v. United States, 207 U.S. 564 (1908).

66. With the exceptions of United States v. Walker River Irrigation Dist., 104 F.2d 334 (9th Cir. 1939), and Conrad Inv. Co. v. United States, 161 F. 829 (9th Cir. 1908), tribal water rights remained unquantified and unprotected.

67. For example, the Fort Hall Indian Irrigation Project on the Shoshone-Bannock Tribes was established for non-Indian irrigators and operated by the Bureau of Indian Affairs by several federal stautues including: Act of Aug. 15, 1894, ch. 290, 28 Stat. 286, 305; Act of Mar. 1, 1907, ch. 2285, 34 Stat. 1015, 1024. See Agreement, supra note 6.

68. See generally Daniel McCool, Command of the Waters: Iron Triangle, Federal Water Development and Indian Water (1987).

69. Homestead Act of 1862, ch. 75, 12 Stat. 392 (1862) (enacted).

70. Desert Land Act of 1877, ch. 107, 1, 91 Stat. 377 (1877); 43 U.S.C. $§ 321$ (2015).

71. MCCoOL, supra note 68.

72. Id.

73. Id.

74. $I d$.

75. Id.

76. 373 U.S. $546(1963)$. 
Practicably Irrigable Acreage ("PIA") standard. ${ }^{77}$ In other words, the reserved right equaled the amount of water which was needed to irrigate all reservation lands which were practically susceptible of irrigation. In 1983, the case reached the Supreme Court again. ${ }^{78}$ The Court affirmed the PIA standard and accepted the Special Master's recommendation as to the quantity of water which should be awarded. ${ }^{79}$ The Special Master's quantity finding that the PIA analysis must include the "economic feasibility" of proposed irrigation projects limits the quantity of water on reservations. ${ }^{80}$ That is, tribal lands will be classified as "practicably irrigable acreage" if it can be demonstrated not only that crops can be grown there, but that they can be grown there economically. ${ }^{81}$

In 1971, the Supreme Court began limiting the federal reserved water rights doctrine in several cases, ${ }^{82}$ and such decisions have adversely affected tribal water rights. For example, in United States v. Dist. Court for Eagle Cnty., the Supreme Court held the McCarran Amendment ${ }^{83}$, which allows the United States to be joined as party in state water adjudications, made no exception for "federal reserved rights." 84 The Court then ruled that the federal enclaves and the tribes represented by the United States would have their federal reserved water rights adjudicated in state court. ${ }^{85}$ The Court made no distinction between the federal reserved rights and the tribes' treaty reserved rights, Winters rights.

In 1983, the Supreme Court in Arizona v. San Carlos Apache Tribe interpreted the McCarran Amendment to allow state courts to exercise jurisdiction to determine Indian water rights in general stream adjudications. ${ }^{86}$ The tribe argued that the disclaimer of jurisdiction in Arizona's statehood act precluded the state from adjudicating Indian property rights. ${ }^{87}$ The Supreme Court concluded that despite the disclaimer the state enabling act was overridden by the McCarran Amendment. ${ }^{88}$ Additionally, the Court held the sovereign immunity of tribes was held not to preclude state court jurisdiction because the McCarran Amendment "waive[d] sovereign immunity with regard to the Indian rights at issue," and a judgment against the United States would be binding on the tribes. ${ }^{89}$

\footnotetext{
77. Id. at 600-01.

78. See generally Arizona v. California, 460 U.S. 605 (1983).

79. Id.

80. February 22, 1982 Special Master Report at 94, adopted in pertinent part, Arizona v. California, 460 U.S. 605 (1983).

81. Id.

82. In Cappaert v. United States, 426 U.S. 128 (1976), the Court reviewed a federal reservation of water rights for a national monument. Upon finding that the implied reservation of water rights doctrine "applies to Indian reservations and other federal enclaves," the Court held that the doctrine "reserves only that amount of water necessary to fulfill the purpose of the reservation, no more." $I d$. at 141 . It further found that the quantification of reserved water rights must be "tailored . . to minimal need." Id. In 1978, the Court further limited the implied reservation doctrine in United States v. New Mexico, 438 U.S. 696 (1978). The case involving a national forest, the Court suggested that the doctrine measures water rights by the minimum necessary to fulfill the reservation's specific purposes for which it was reserved. Id. at 699-700.

83. In 1952, Congress enacted the McCarran Amendment, 43 U.S.C. $\$ 666$ (2012), which waived sovereign immunity and allowed the United States to be joined in state court actions to quantify water rights. The act applies, however, only to general stream adjudications of an entire river basin, and not to administrative proceedings or lawsuits over individual water rights. Id.

84. 401 U.S. 520, 255-526 (1971).

85. Id.

86. See Arizona v. San Carlos Apache Tribe, 463 U.S. 545 (1983).

87. Id. at 558 .

88. Id. at $563-564$

89. Id. at $566 \mathrm{n} .17$ (emphasis omitted).
} 
Following this decision, many tribes faced the difficult decision to litigate in a state court or negotiate their water rights with the federal and state governments. Several tribes have chosen to litigate their reserved water rights in often exhaustive, contentious, and uncertain state river adjudications rather than seek settlement negotiations. ${ }^{90}$ State court adjudication of Winters rights provides locally elected state judges with the opportunity to decide federal water rights issues, which may not be in the best interest of tribes. ${ }^{91}$ And, litigation can have a narrow focus that may prevent consideration of alternative ways of solving issues that might lead to some mutually acceptable solutions. Settlements, on the other hand, are well suited for the parties to create solutions in a contemporary setting. They provide an opportunity in which the parties can seek the proverbial win-win outcome, to build ongoing relationships and cooperation, have greater flexibility, and resolve a wide variety of issues.

From 1978 through 2013, Congress enacted thirty Indian water settlement acts into law, which were successfully negotiated among tribes, states and the federal governments. ${ }^{92}$ Numerous other water settlements have been concluded without Congressional approval, e.g. the Confederated Tribes of the Warm Springs Reservation in the State of Oregon and the Assiniboine and Sioux Tribes of the Fort Peck Reservation in Montana. ${ }^{93}$ These negotiated settlements affect tribes in eight western states including Idaho, Nevada, Utah, Colorado, Montana, California, New Mexico, and Arizona. Importantly, these settlements are much more than just a water settlement, they are major government-to-government agreements involving the sovereignty of tribes and the settlements decide issues of control of water and the future for tribes.

At the heart of every negotiated tribal water settlement act is a quantification of the tribal right to water. In nearly all settlements, tribes are required to relinquish their right to future claims to reserved water rights forever, and their water claims against the United States. These are major concessions tribes make in settlements. In general, tribes also often agree to a lesser quantity of water than they could receive under the Winters approach of securing sufficient water to fulfill the purposes for which the land was set aside. In exchange, the tribes bargain for and receive guarantees of direct funding as part of the deal from the United States and states in developing their water resources, and receiving long-overdue water supplies.

One of the primary advantages of water settlements is they are flexible and tailored to the needs and circumstances of the parties. Indeed, negotiated Indian water rights settlements have been utilized to address the scarcity of surface water and ground water due to over appropriation, over use, waste and drought conditions. The parties to these negotiated settlements include a host of interests - tribes, federal government, state and local

90. See, e.g., State ex rel. Martinez v. Lewis, 861 P.2d 235 (N.M. Ct. App. 1993) (consolidated cases involving the Mescalero Apache Tribe of southern New Mexico); In re Gen. Adjudication of All Rights to Use Water in Big Horn River Sys., 753 P.2d 76 (Wyo. 1988), aff'd, 492 U.S. 406 (1989) (equally divided court).

91. Wolfley, supra note 13, at 53.

92. See Darcy S. Bushnell, American Indian Water Rights Settlements, UTtON TRANSBOUNDARY RESOURCES CENTER, http://uttoncenter.unm.edu/pdfs/American_Indian_Water_Right_Settlements.pdf (last visited Sept. 9, 2015) (listing of negotiated Indian water settlements).

93. Id. 
governments, water districts and associations, water users, irrigators, and the general public is often given the opportunity to comment. The issues in these negotiations are complex and important, and each party compromising in order to achieve the most important goal, a dependable water supply. These water settlements reached after many years of negotiations and during drought times illustrate how parties can "work together in a spirit of cooperation, not antagonism" as urged by the Arizona Supreme Court in the Gila River adjudication. ${ }^{94}$

\section{NEGOTIATING WATER FOR THE TRIBAL HOMELAND}

As discussed above, the disadvantages of state general stream adjudications for tribes are well documented. Litigation is extremely expensive, time-consuming, and takes place in a potentially hostile state forum. ${ }^{95}$ These issues for tribes coupled with a federal policy of favoring settlement over litigation ${ }^{96}$ led the Shoshone-Bannock Tribes to consider a negotiated settlement to secure and confirm their senior right to water in the Biagaweit for their homeland, the Fort Hall Reservation.

\section{A. The Negotiations}

In 1985, the Idaho Legislature authorized the adjudication of all claims to the use of water within the Snake River Basin in Idaho. The Snake River Basin Adjudication ("SRBA") district court issued an order commencing the adjudication on November 19, 1987. The legislature also directed the State to engage in good faith, government-to-government negotiations with Shoshone-Bannock Tribes. ${ }^{97}$ After commencement of the SRBA all persons believing that they had rights were required to file claims to those water rights with the Idaho Department of Water Resources. IDWR investigated the claims and filed its recommendation regarding the existence and nature of those rights with the SRBA district court.

The Shoshone-Bannock Tribes' decision to enter into water rights negotiations was not an easy one, but the adjudication of their water rights in a state court, following the Arizona v. San Carlos Apache Tribe case, was not a satisfactory solution either. The Shoshone-Bannock were well aware of the challenges their relatives of the Eastern Shoshone Tribe located on the Wind River Reservation in Wyoming were facing in the Wyoming state court in the Big Horn River Adjudication. ${ }^{98}$ Certainly, the case of In re General 68 (2001).

94. In re Gen. Adjudication of All Rights to Use Water in the Gila River Sys. \& Source, 35 P.3d

95. See generally Reed D. Benson, Can't Get No Satisfaction: Securing Water for Federal and Tribal Lands in the West, 30 ENVTL. L. REP. 11056 (2000); Susan D. Brienza, Wet Water v. Paper Rights: Indian and Non-Indian Negotiated Settlements and Their Effects, 11 STAN. ENVTL. L.J. 151, 164-68 (1992).

96. See Working Group in Indian Water Settlements; Criteria and Procedures for the Participation of the Federal Government in Negotiations for the Settlement of Indian Water Rights Claims, 55 Fed. Reg. 9223 (Mar. 12, 1990).

97. H. Con. Res. 16, 48th Leg., 1st Sess. (Idaho 1985). Exec. Order Nos. 85-9 and 87-9 provided that it was in the interest of the State of Idaho to settle through negotiated agreements, if possible, all claims for water rights reserved under federal law.

98. See generally Treaty with the Eastern Band Shoshoni and Bannock, Bannock Tribes -Eastern Shoshonee Tribes-U.S., July 3, 1868., 15 Stat. 673 (The Shoshone-Bannock Tribes and Eastern Shoshone are signatories to the Fort Bridger Treaty). 
Adjudication of All Rights to Use Water in Big Horn River System ${ }^{99}$ is an example of a case adversely affecting the Shoshone and Arapaho Tribes. For instance, the Wyoming Supreme Court found an exclusively agricultural purpose for the reservation and thus awarded surface water for only irrigation, municipal, domestic, commercial and livestock uses. ${ }^{100}$ It rejected the Tribes' claims to preserve instream flows for fishery preservation, mineral, industrial, wildlife and aesthetic purposes. ${ }^{101}$ The Wyoming Supreme Court also refused to apply the Winters doctrine to groundwater. ${ }^{102}$ The Court also subjected the Eastern Shoshone Tribes water uses to state law for administration purposes. ${ }^{103}$ Although the tribes obtained a fairly large reserved water right, ${ }^{104}$ the court decree has placed limitations on the tribes' ability to actually receive the benefits from the water right. ${ }^{105}$

In the end, after much deliberation, negotiation was chosen to be the more suitable process. Two Memoranda of Understanding (MOU) established the framework for negotiations. On August 30,1985, the Tribes and State agreed in an MOU to commence good faith negotiations as early as October $15,1985 .{ }^{106}$ In addition to the Tribes and State, the United States and private water users participated in the negotiations. ${ }^{107}$ The Committee of Nine, representing Idaho water users, signed the second MOU on May 19, 1987.108

The State, United States and Tribes, entered into another agreement, entitled a "Technical Studies Agreement" to establish a methodology for the review of the Tribes' reserved water rights claims and to identify matters for further discussion and analysis. ${ }^{109}$ This second MOU was significant because the parties rather than a court-appointed special master determined how to evaluate the tribal water claims. ${ }^{110}$ Water engineers hired by each respective party participated in extensive studies and analysis to evaluate and support the source, basis of right, diversions, priority dates, present and future acres, and use rights. ${ }^{111}$

99. See generally General Adjudication of All Rights to Use Water in Big Horn River System, 753 P.2d 76 (Wyo. 1988), aff'd by an equally divided court sub nom, Wyoming v. United States, 492 U.S. 406 (1989) [hereinafter Big Horn River System].

100. Id. at 94, 96, 100-01 ("[W]e have no difficulty affirming the finding that it was the intent at the time to create a reservation with a sole agricultural purpose.").

101. Id. at $100-01$.

102. Id. at $92,100-01$.

103. Id. at $108-09$

104. The Wyoming Supreme Court awarded the Eastern Shoshone Tribe 499,762 acre-feet per year of water for their 2.2 million acre Wind River Reservation. In contrast, the Shoshone-Bannock Tribes negotiated a settlement of 581,031 AFY water for their 544,000 acre Fort Hall Reservation, and includes water rights for all consumptive uses, and groundwater rights.

105. See Big Horn River System, supra note 99.

106. This MOU was later extended in January 10, 1986. See Agreement, supra note 6, at arts. 3.7, 3.9 .

107. Id.

108. The Committee of Nine is not a legal entity, but rather an advisory committee of private, nonIndian water users in Water District 01, which encompasses the Upper Snake River Basin above Milner Dam. Although the Committee of Nine has no legal authority to bind any private water user, it is composed of the representatives of the nine largest irrigation companies and accordingly has a great deal of political clout in the State of Idaho. Article 4.11 of Agreement. The Tribes and United States were assured that if the Committee of Nine supported the Agreement, which it did, then there would be little, if any, opposition by private water users or Idaho legislators.

109. See Big Horn River System, supra note 99.

110. Id. 
The Tribes sought to accomplish four basic goals in the negotiations. First, securing "wet water" not a "paper water right" was paramount to the Tribes. A stable, continuing water supply was critical to ensure the survival and existence of the People and its future generations, and ensure a viable economy on the 544,000 acre Reservation, which is comprised of $98 \%$ Tribal trust lands, and $2 \%$ individually owned lands by Tribal members and non-Indians. ${ }^{112}$ Additionally, the Tribes' economic base consists of large agricultural production of potatoes, wheat and alfalfa that require a dependable source of water. ${ }^{113}$

Second, the Tribes sought to secure the majority of water through natural flows and storage of water for the Fort Hall Reservation. From the Tribal cultural view, water is more valuable than money, as it is the origin for the Shoshone and Bannock people. Accordingly, it is important to have the sacred water available on and flowing through the Reservation. Therefore, the Tribe were not as concerned with securing money as securing an ample supply of water for present and future generations. Third, it was crucial to have the flexibility to use various sources of water for various uses. The Tribes desired to use their rights in irrigation, domestic, commercial, municipal, industrial, stock uses, instream flows, and the ability to market water off-Reservation. Fourth, the Tribes sought to create a settlement document that was reality based. There was an abundance of water in the Biagaweit, Blackfoot and Portneuf Rivers to meet the Tribes' needs and claims. The challenge was to craft an agreement with the United States and State of Idaho to accomplish the Tribal goals.

\section{B. The 1990 Fort Hall Indian Water Rights Agreement}

Five years after the initial MOU to commence negotiations, the Tribes, State of Idaho, United States, and the Committee of Nine of Water District 01 reached agreement on July 10, $1990 .{ }^{114}$ Under the Agreement, ${ }^{115}$ the Tribes, Tribal members and Tribal allottees may divert up to 581,031 AFY (acre-feet per year) of water from the Snake River basin for present and future uses of the Tribes. ${ }^{116}$ The water supply for the Tribal water rights is a combination of natural flow, groundwater and federal contract storage water. ${ }^{117}$

The primary legal basis for the Tribes' water rights is the Winters doctrine. ${ }^{118}$ The Fort Hall Reservation was created by Order of President Johnson, dated June 14, 1867,

112. See FMC v. Shoshone-Bannock Tribes, 905 F.2d 1311 (9th Cir. 1990).

113. See SHOSHONE-BANNOCK TRIBES, http://www.shoshonebannocktribes.com/.

114. Agreement, supra note 6.

115. Id.

116. Id. at art. 6.2.

117. See id. at art. 7.

118. Id. at art. 6.1 (making clear that the Winters doctrine is the basis for the Tribes rights to use waters "arising on, under, flowing across, adjacent to, or otherwise appurtenant to the Reservation"). 
for the Boise and Bruneau Bands of Shoshone and Bannock Tribes. ${ }^{119}$ It originally encompassed 1.2 million acres, but was diminished through two cession agreements. ${ }^{120}$ Today, it is approximately 544,000 acres, of which $98 \%$ are Indian owned. ${ }^{121}$ The underlying reports recommending creation of the Reservation indicate the purpose of the Reservation was so that, "the Indians of all the bands referred to should have some fixed home set apart for them before the lands occupied by the whites, who are rapidly prospecting the country ... ."122 Washakie's Band of Shoshone and the Taghee for the Bannock Tribe entered into a treaty with the United States on July 3, 1868, which is same treaty that created the Wind River Reservation. ${ }^{123}$ The 1868 Fort Bridger Treaty confirmed the Fort Hall Reservation for the Shoshone. ${ }^{124}$ Article 2 of the Treaty provided for the Bannocks to be secure a reservation created in the "Portneuf" and "Kansas" (typographical error, rather it should have been "Camas") Prairie countries."125 Subsequently, the Bannocks were settled on the Fort Hall Reservation in contravention of the provisions in the 1868 Treaty guaranteeing the Bannocks a separate reservation. ${ }^{126}$

The parties utilized the practicably irrigable acreage standard to quantify the tribal water rights. ${ }^{127}$ In doing so, they relied on the lands under agriculture and other lands which could potentially be farmed. ${ }^{128}$ Agricultural production in the form of potato, alfalfa, and wheat farming have been a major economic pursuit for the Tribes for many years. ${ }^{129}$ Accordingly, water for irrigation was a paramount priority. ${ }^{130}$ In addition, the Tribes realized that other uses of water were important in the future in case the agricultural economy decreased. ${ }^{131}$ The Tribes, therefore, secured water marketing provisions, instream flows, and transfers and diversions provisions for water. ${ }^{132}$

Article 7 of the Agreement was the most time consuming provision to negotiate, requiring extensive work by meetings among the various technical experts, as well as

119. Fort Bridger Treaty, supra note 16.

120. The first one, ratified by Congress on September 1, 1888, ceded lands to the United States to be sold to settlers within the townsite for the town of Pocatello. Act of Sept. 1, 1888, ch. 936, 25 Stat. 452. In the second cession Agreement, approved by Congress on June 6, 1900, 31 Stat. 672, the Tribes reserved the "right, without any charge therefore, to cut timber for their own use, but not for sale, and to pasture their livestock on said public lands, and to hunt thereon and to fish in the streams thereof." Act of June 6, 1900, ch. 813 , art. 4,31 Stat. 672 at 674.

121. See FMC v. Shoshone-Bannock Tribes, 905 F.2d 1311 (9th Cir. 1990).

122. Letter from the Comm'r of Indian Affairs (May 23, 1867), reprinted in ICHARLES J. KAPPLER, INDIAN AFFAIRS, LAWS, AND TREATIES, 835 (1904). The Commissioner further explained that the Reservation's "location as a permanent home for those bands is dependent upon the consent of Washakie's band, commonly known and treated as the eastern bands Shoshone ...." Id.

123. Fort Bridger Treaty, supra note 16, at art. 2.

124. Id.

125. Id.

126. See Swim v. Bergland, 696 F.2d 712 (9th Cir. 1983).

127. See generally Agreement, supra note 6.

128. Id.

129. Id.

130. Id.

131. Id. at arts. $4.14,6.2$.

132. Agreement, supra note 6, at arts. 4.14, 6.2 (defining "DCMI" to include domestic, commercial, municipal and industrial uses of water. Art. 6.2 quantities the Tribal water right for present and future uses in the Upper Snake River Basin as an annual diversion of 581, 031 AFY from the Snake River Basin for irrigation, DCMI, instream flow, hydropower and stockwater purposes. Also, none of the Tribal water rights can be deemed relinquished, forfeited or abandoned because of nonuse.). 
negotiators, representing the Tribes, United States, the State and the Committee of Nine. ${ }^{133}$ It is the most important Article because it identifies and quantifies, with priority dates, each of the discrete surface water (Article 7.1) and groundwater (Article 7.2) rights which collectively comprise the total Tribal water right of 581,031 AFY, establishes the annual diversion volume, diversion rate, annual volume of consumptive use, and Winters rights for each right. ${ }^{134}$ This Article secures and confirms the Tribes' water rights in the various water systems on and off-reservation. ${ }^{135}$

The Agreement is an innovative settlement that utilizes the various water sources in the Upper Snake River Basin. ${ }^{136}$ The Tribes negotiated rights for surface, ground, and federal contract storage water based on the Winters doctrine, prior court decrees and the Fort Hall Indian Irrigation Project. ${ }^{137}$ Water uses allowed under these rights reflect a sophisticated water management plan for the irrigation of lands. ${ }^{138}$ The water rights may be applied to all consumptive uses. ${ }^{139}$

Importantly, the parties did not have to negotiate any construction of future federal water projects to transfer water to the Fort Hall Reservation, which means the goal of obtaining "wet water" was accomplished. ${ }^{140}$ In the Upper Snake River Basin there are established federal reservoirs, including Jackson Lake, Palisades, Ririe, Blackfoot and American Falls which store millions of acre feet of water. ${ }^{141}$ Additionally, the Snake River, Blackfoot River, and Portneuf River, and numerous tributaries and creeks flow through the Fort Hall Reservation. ${ }^{142}$ These water sources are combined to supply surface and groundwater to the Reservation and meet the Tribes' present and future needs. ${ }^{143}$

The Tribes received groundwater use rights up to 125,000 acre-feet per year from any ground water source within the Reservation, and up to 23,500 AFY in the Bannock Creek Basin. ${ }^{144}$ Significantly, the parties recognized the relationship of surface and groundwater in the Agreement. Accordingly, the Tribe may utilize surface water first and if the total water available falls short the Tribes may divert sufficient groundwater within the Reservation to make up for the shortfall. ${ }^{145}$

The Tribes have the right to create the Shoshone-Bannock Water Bank to rent for use off the Reservation water stored in the American Falls and Palisades Reservoirs not used on Indian lands or exchanged for diversions in the Portneuf River. ${ }^{146}$ The creation of the water bank by the Tribes is to facilitate their right under Article 7 to rent for any

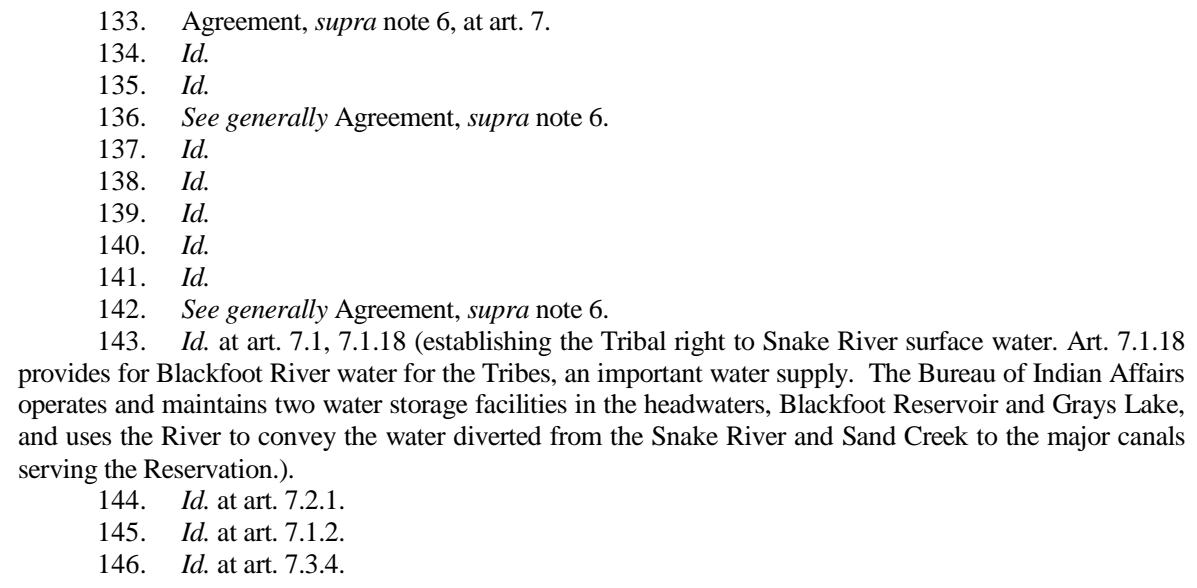

143. Id. at art. 7.1, 7.1.18 (establishing the Tribal right to Snake River surface water. Art. 7.1.18 provides for Blackfoot River water for the Tribes, an important water supply. The Bureau of Indian Affairs operates and maintains two water storage facilities in the headwaters, Blackfoot Reservoir and Grays Lake, and uses the River to convey the water diverted from the Snake River and Sand Creek to the major canals

144. Id. at art. 7.2.1.

145. Id. at art 7.1.2.

146. Id. at art. 7.3.4. serving the Reservation.). 
beneficial use outside the Reservation all or any of the water accruing to the storage space in American Falls and Palisades Reservoirs. ${ }^{147}$ The rented water may be used for any beneficial use, provided that water stored in the Palisades Reservoir is used within the Snake River Basin above Milner Dam. ${ }^{148}$ Water stored in the American Falls Reservoir may be used in the Snake River Basin anywhere in Idaho. ${ }^{149}$ The rentals shall not be limited by any provisions of federal contracts (other than the exchanges in the Michaud Irrigation Project contract), any reduction of water available under other existing rights, or any conflict with the public welfare or local public interest of citizens of Idaho. ${ }^{150}$

The water bank provision coupled with the Tribes right to transfer or rent with the Reservation all or any portion of the Tribal water rights in Article 7 subject to certain conditions gave the Tribes a significant and viable marketing capability. ${ }^{151}$ The Tribes have implemented these provisions and entered into rental agreements to supply water to the U.S. Bureau of Reclamation for purposes of anadromous fish flows, and Idaho Power for hydropower generation. ${ }^{152}$

Water marketing ${ }^{153}$ was hotly negotiated because the State of Idaho and Committee of Nine contended Winters rights were reserved for use only on the Reservation. ${ }^{154}$ After much deliberation, the Tribes and United States agreed to not market their Winters rights, but instead to market water accruing to the storage space held by the United States in Palisades and American Falls Reservoirs, and market any water within the Reservation. 155

The Agreement provides three sources of water rights to enhance instream flows. First, the Tribes may use its stored water used, exchanged, or rented to augment instream flows for river reaches on or adjacent to the Reservation. ${ }^{156}$ Second, the Tribes have the right to use for instream flows the natural flows for all waters arising wholly within and traversing reservation lands. ${ }^{157}$ Third, the Tribes may use up to 15,000 af/yr from the 1907 right on the Blackfoot River and the 1919 right in Grays Lake for instream flows in reaches of the Blackfoot River. ${ }^{158}$

147. Id. at art. 7.3.1.

148. Agreement, supra note 6, at art. 7.1.2.

149. Id. at art. 7.3.4.ii

150. Id. at art. 7.3.5.

151. Id. at art.7.

152. See IDAHO Power, InTEgRated Resource Plan 30 (2015), https://www.idahopower.com/pdfs/AboutUs/PlanningForFuture/irp/2015/2015IRP.pdf (discussing the Tribral rental agreement between the Shoshone-Bannock Tribe and Idaho Power); see also WASH. STATE DEP'T OF ECOLOGY, ANALYSIS OF WATER BANKS IN THE WESTERN STATES, 75 (2004), https://fortress.wa.gov/ecy/publications/publications/0411011.pdf (discussing multi-year lease between Shoshone-Bannock Tribal Water Bank and United States of America, acting through the Reginal Director, Pacific Northwest Region for the Bureae of Reclamation).

153. See David H. Getches, Management and Marketing of Indian Water: From Conflict to Pragmatism, 58 U. Colo. L. REV. 515 (1988); Lee H. Storey, Comment, Leasing Indian Water Off the Reservation: A Use Consistent with the Reservation's Purpose, 76 CALIF. L. REV. 179 (1988) (Water marketing includes the sale or long-term lease of tribal water to non-Indian state water users, government entities and municipalities who may need water, and also promotes tribal self-sufficiency and permits tribes to make full use of their reserved water).

154. See Getches, supra note 153; Storey, supra note 153.

155. Agreement, supra note 6, at art. 7.5.

156. Id. at art. 7.4.

157. Id. at art. 7.

158. Id. at arts. 7.19, 7.20 
The Tribes may transfer or lease within the Reservation all or any portion of their water rights to any beneficial use. ${ }^{159}$ The transactions may be completed without any notice to other water users, but the transfers must not exceed the maximum diversion rate, annual volume of diversion, and annual consumptive use of the original use. ${ }^{160}$ Other than three rights (Lincoln Creek, Ross Fork and the Portnef River), water may be transferred any place within the Reservation. ${ }^{161}$

The Tribes may change the points of diversion and periods of use of their rights for any beneficial use, provided the change does not exceed the maximum diversion rate, the annual volume of diversion, the annual volume of consumptive use or injure other water rights. ${ }^{162}$ Before the Tribe or United States can exercise their Snake River water right, they are required to publish a notice of transfer. ${ }^{163}$

The administration of water rights and the role of a tribe, state and federal governments has been a contentious issue in water right settlements. The issue simply stated was whether and to what extent the State of Idaho may control Tribal and federal water use on the Reservation. The issue revolved around the interpretation of the McCarran Amendment. ${ }^{164}$ The United States' position was based on Colville Confederated Tribes v. Walton, the McCarran Amendment does not "expand[] the state's regulatory powers over water on a federal reservation." 165 The issue was extremely difficult to resolve and in the case of the Blackfoot River was not resolved, but rather the parties agreed to administer the river as it had been administered in the past. ${ }^{166}$

In the Agreement, however, the parties agreed to "cooperate in the administration of water resources" 167 to protect the use of all water rights decreed in the SRBA. Under the Agreement, the Tribes shall administer the distribution of all Tribal water rights within the Reservation pursuant to a water code submitted to and approved by the Secretary of Interior. ${ }^{168}$ There are a few water rights used on lands owned by non-Indians within the Reservation, which are administered by the State although the United States and Tribes have the right to inspect and monitor these diversions. ${ }^{169}$ The State utilizes the assistance of the Tribal Water Resources Department in the administration. The United States is responsible for administering the distribution of the Fort Hall Indian Irrigation Project water rights from the point water is delivered to the project facilities. ${ }^{170}$

The State is permitted to continue administer water rights in the Snake River under the direction of the water master, up to the diversion point for the Fort Hall Reservation canal (located upstream from and outside the boundaries of the Reservation). ${ }^{171}$ The State

159. Id. at art. 7.5.

160. Id. at art. 7.3.9

161. Agreement, supra note 6, at art. 7.3.1.

162. Id. at art. 7.6.

163. Id. at art. 7.6.

164. See McCarran Amendment, supra note 83.

165. 647 F.2d 42, 53 (9th Cir. 1981).

166. Agreement, supra note 6, at art. 8.3. During implementation of the Agreement, the parties entered into additional stipulations filed with the SRBA to resolve the water rights of non-Indian users to Blackfoot River water, and administration of water on the river.

167. Id. at art. 8.1.

168. Id. at art. 8.2.3. The Tribes' Water Code was approved in 2010 and they are issuing permits and administering water rights.

169. Id. at art. 8.2.7.

170. Id. at art. 8.2.5.

171. Id. at art. 8.4.1. 
has agreed to and is providing water distribution and flow accounting data from the Snake and Blackfoot Rivers to the Tribal Water Resources Department on a regular basis. With the increase in data gathering and computerized water monitoring devices the parties are able to secure real-time data on water flows through the upper basin of the Snake River.

The parties were unable to agree on their respective authority to administer the Blackfoot River. ${ }^{172}$ Over the years there had been two water masters, one from the State and one from the Bureau of Indian Affairs, who communicated on a daily basis during the irrigation season and worked out disputes. The State would not agree to put this status quo in writing, instead wanted the state water master to control the administration. To avoid litigation on the issue, the parties agreed to "administer the water rights decreed in the SRBA from the Blackfoot River as water rights have been administered in the past." 173 The parties agreed to negotiate a comprehensive Blackfoot River Management Plan (Plan) subsequent to the Agreement, and install monitoring devices and provide for parties to have access to inspect devices and diversions. ${ }^{174}$ The parties finalized and submitted the Plan to the SRBA in 2013.

The Tribes received federal and state contributions in the settlement. First, it received federal appropriations to acquire 9,000 acres of land and grazing rights at Grays Lake, located off-Reservation. ${ }^{175}$ Second, appropriations were allocated to assist the Tribes in implementing the Tribal water management system. ${ }^{176}$ And, finally, the State of Idaho contributed in-kind services to assist in the implementation of the Agreement. ${ }^{177}$

Article 9 of the Agreement creates a three-member "Intergovernmental Board" which is composed of the Chairman of the Fort Hall Business Council, the Director of the Idaho Department of Water Resources, and the Secretary of Interior, or their designees. ${ }^{178}$ It serves two functions, first, to mediate or resolve disputes under the Agreement. ${ }^{179}$ It has no legal authority to direct a party to do something, and any unresolved disputes would go before a court de novo. ${ }^{180}$ Second, it provides a place for hearing disputes concerning changes in points of diversion or periods of use of the tribal water right Snake River and Sand Creek. ${ }^{181}$

Although the Tribes secured an Agreement and a partial final court decree was issued by the SRBA court in 1995, the Tribes have been required to be ever vigilant to protect their water rights. Many claims filed by non-Indian users in the Upper Snake River Basin claimed Tribal water, Tribal priority dates, Tribal lands as place of use, or in general adversely impacted the Tribal water rights. The Tribes filed over 700 objections to water rights claims in the SRBA, and mediated or attended court hearings to preserve their rights. In addition, the Tribes successfully challenged the City of Pocatello's claims to share the Tribal priority date based on the 1888 cession agreement, an issue left open

172. Agreement, supra note 6, at art. 8.3.

173. Id. at art. 8.3.

174. Id. at arts. 8.3.2-3.

175. Id. at art. 7.19 .

176. Id. at art. 8.3.

177. Id. at art. 8.4.

178. Agreement, supra note 6, at art. 9.2

179. Id. at art. 9.3.

180. Id. at art. 10.1.

181. Id. at art. 10. 
in the Agreement. ${ }^{182}$ The Tribes are continuing to resolve several issues left open in the Agreement.

\section{CONCLUSION}

The Shoshone-Bannock Tribes, the first tribe to negotiate and settle its water rights in the SRBA, faced daunting challenges as they struggled to protect and preserve their water rights for their community and peoples. Securing a water settlement or entering into water rights negotiations or litigation is not a simple process under the best of circumstances and rarely are "best" circumstances pervasive when so many competing interests are coveting the precious resource - water. Viewed from a legal perspective, settlement of the Tribes' water rights in the Snake River Basin Adjudication confirms the promises made in the Fort Bridger Treay of 1868 that reserved the Fort Hall homeland for the Shoshone and Bannock peoples. The Shoshone-Bannock Tribes sought to fulfill the century-old hope and ultimate promises of the treaties and agreements to provide a native separatism, a viable permanent home for present and future generations to live, dream and flourish. The settlement also recognizes the Winters doctrine in reserving water for present and future generations of Tribal peoples.

Viewed in the context of tribal culture, use of the Tribal Creation story and values connected to the sacred water preserved the Shoshone and Bannock way of life-Tribal culture, language, identiy, spirituality and sense of place-for future generations. Viewed in a spiritual context, use of the Creation Story acknowledges and perpetuates the link to water and the holy landscapes the Shoshone and Bannok peoples believe the Creator gave them. The Tribes, based on their cultural teaching sought to negotiate and craft creative solutions with the federal and state governments whereby the Tribal strategies respected and reinforced their own cultural values based upon their origin story. That is, the Tribes sought to secure and preserve a supply of water for their homeland; water to be respected and used in their daily lives, and their ceremonies.

One thing is certain, the Tribes sought to secure water for their homelands, a place where tribal people can continue to practice their age-old traditions taught by their ancestors and the Creator. Water is indispensable to confirming the sacred treaty promises. Water is essential to confirming our very being. And, Biagaweit will remain integral in the lives of the Shoshone and Bannock Tribes.

182. Agreement, supra note 6, at art. 11.12; City of Pocatello v. State, 180 P.3d 1048 (Idaho 2008) (holding the 1888 Cession Agreement with the United States for lands establishing the City of Pocatello that provided the city residents "use in common with" the Indians of on-reservation waters near the town, did not grant the city a right to water, but only rights of access and construction of facilities). 